\title{
Is a Mid-Sized Town Enough for the Generation Z? What is Needed to Keep the Young People in Their (Home) Town?
}

\author{
NIKOLETTA TÓTH-KASZÁS \\ University of Pannonia, Hungary \\ kaszas.nikoletta@uni-pen.hu
}

\begin{abstract}
My research focuses on the settlement aspects of nonbusiness marketing. It highlights a problem, which today many domestic and rural communities are struggling with: the out-migration of young people. This long-lasting problem in the rural environment has continued in the 2010 s and affects not only villages, also small towns. Many research results indicate that retention of young workforce is a generic problem in Hungary today, almost in every settlement. In my empirical research, I take into account actors that act in a non-profit-making way but in the direction of social interests; that is to say, what can the non-business sector (local government, municipal government, public utilities, civil spheres, educational units) make in terms of marketing in order to accommodate talented young people. The interviews partly focused on the identity of the leaders, their impressions about the town, and party on the percept characteristics of Generation Z; they also emphasized what such a non-business institution can do in order to keep them in the town. My research is given by two seemingly distinct areas whose relationship is nevertheless undisputed. The exploration of the characteristics and values of the $\mathrm{Z}$ generation is essential in order to find the proper way of communicating with them and to shape the future of a town that offers them a perspective. With it, you cannot avoid the migration of young people in the capital; however, it can offer an option for rural towns to slow down this process.
\end{abstract}

Key words: generation Z, middle-sized town, nonbusiness institutions, settlement development

https://doi.org/10.26493/1854-4231.13.33-48

\section{Generations}

THE BASES OF GENERATION THEORY

The generation theory is based on the approach that people who were born in the same era, formed by the same period and have the same social markers on them are - in some respects - similar to each 
TABLE 1 Different Generational Approaches, Delimitations

\begin{tabular}{|c|c|c|c|}
\hline $\begin{array}{l}\text { Howe and } \\
\text { Strauss } \\
(1991)\end{array}$ & $\begin{array}{l}\text { Lancester and } \\
\text { Stillman } \\
(2002)\end{array}$ & $\begin{array}{l}\text { Oblinger and } \\
\text { Oblinger } \\
(2005)\end{array}$ & $\begin{array}{l}\text { Mccrindle } \\
\text { Research } \\
(2012)\end{array}$ \\
\hline $\begin{array}{l}\text { Silent generation } \\
\left(1925^{-1943)}\right.\end{array}$ & $\begin{array}{l}\text { Traditionalist } \\
(1900-1945)\end{array}$ & $\begin{array}{l}\text { Mature } \\
\text { (before 1946) }\end{array}$ & $\begin{array}{l}\text { Builders } \\
(1925-1945)\end{array}$ \\
\hline $\begin{array}{l}\text { Boom generation } \\
\left(1943^{-1961)}\right.\end{array}$ & $\begin{array}{l}\text { Baby boomers } \\
(1946-1964)\end{array}$ & $\begin{array}{l}\text { Baby boomers } \\
(1947-1964)\end{array}$ & $\begin{array}{l}\text { Baby boomers } \\
(1946-1964)\end{array}$ \\
\hline $\begin{array}{l}\text { Generation } 13 \\
(1961-1981) \\
\end{array}$ & $\begin{array}{l}\text { Generation X } \\
(1965-1980)\end{array}$ & $\begin{array}{l}\text { Gen-Xers } \\
\left(1965^{-1980)}\right.\end{array}$ & $\begin{array}{l}\text { Generation X } \\
(1965-1979) \\
\end{array}$ \\
\hline $\begin{array}{l}\text { Millenium } \\
\text { generation } \\
(1982-2000)\end{array}$ & $\begin{array}{l}\text { Millenium/Y/ } \\
\text { Future Generation } \\
(1981-1999)\end{array}$ & $\begin{array}{l}\text { Gen-Y, NetGen, } \\
\text { Millenium } \\
(1981-1995)\end{array}$ & $\begin{array}{l}\text { Generation } \\
(1980-1994)\end{array}$ \\
\hline- & - & $\begin{array}{l}\text { Followers of } \\
\text { Millenials } \\
\text { (after 1995) }\end{array}$ & $\begin{array}{l}\text { Generation Z } \\
\left(1995^{-2010)}\right.\end{array}$ \\
\hline
\end{tabular}

Notes Adapted from Bálint (2016) and Pierog, Erdei, and Gergely (2016).

other and can be described with common features. In other words, the generation is a group of people associated with the same age and life stage, living conditions and technology, events and experiences (McCrindle and Wolfinger 2009). Understandably, in a given historical period, people living in the same economic, political and social conditions are reached by the same impulses, so their peculiarities and common characteristics develop.

The generation theory is linked to two American authors, William Strauss and Neil Howe. In their book named Generations (1991) they found that the members of a given generation behave very similarly, they have a certain worldview and value system. Individual generations change each other approximately in every 20-25 years, naturally with soft passages, possibly overlapping. According to the authors, every generation has its own human type.

Several theories have been proposed to label and to appraise the generations, mostly depending on which country the approach comes from. Bálint (2016) and Pierog, Erdei, and Gergely (2016) pointed out that the generational classification was not even uniform. Different approaches are presented in table 1.

We can see that the generation theory itself begins to deal with people of the 2oth century, and especially with those born after 1925 . The generation born after the turn of the millennium (and is in the focus of this study) is by the literature typically referred to as a generation Z (Steigervald 2014; Tari 2015), but they are also referred to as 'Facebook Generations,' Digital Natives (Prensky 2001), Zappers, 'Instant Online' ages (Mutte 2004), dotcom kids, net genera- 
tion, iGeneration, or C generation, which got its name after the word connection (Törőcsik, Szűcs, and Kehl 2014).

The above presented theoretical approaches have been developed fundamentally for the American society. According to Árvané et al. (2017) these approaches and names are today used in other continents and countries, however, differences are permissible.

The generation theory was widely criticized, since in many cases it is difficult to distinguish if something is really a property of a specific generation, or it simply comes from the age-specific features of the generation (Parry and Urwin 2011). Mannheim (2001) drew attention on the fact that the similarity of the date of birth is still not enough to be called a group of people a common generation. In his opinion, it is required for all members of a group called a generation to experience common events during their upbringing that may make them feel different from those who had been born before and later. Some also argue that there are significant differences between different generations (Eskilson and Whiley 1999; Levy et al. 2005).

In my research, I agree with the standpoint of Törőcsik, Szücs, and Kehl (2014), that there are generational differences and similarities, but the relationship between the members of the given generations is loose. This means that even though the values are similar because of the perceived social, economic, political experiences, the individual lives can shade this picture significantly, therefore it is not possible to generalize. I accept, however, that there are differences between generations and similarities within the generations. Communication between generations is considered as a special type of intercultural communication, where conflicts are usually based on value differences (Malota and Mitev 2013; Malota 2011).

THE VALUES OF GENERATION Z

During my research carried out in Hungary, I regard young people as members of the $\mathrm{Z}$ generation who were born in 1995-2005. Some authors call this group postmillennialists, others 'Facebook generation' or even digital natives. Frequently called zappers, 'Instant online' age, 'dotcom' kids, netgeneration, iGeneration also. Others call them $\mathrm{C}$ generation, which is named after the word connection, and $\mathrm{D}$, which refers to the digital word, but also to $\mathrm{R}$, which is derived from the responsibility, i.e. liability (Törőcsik, Szúcs, and Kehl 2014).

These young people, who in 2018 are currently 13 and 23 years old, are fully in possession of digital knowledge. They are growing up (or had grown up) in families, where the parents have been well aware of the technological advances. The $\mathrm{Z}$ generation is the first global generation. Because of the Internet and worldwide connections, the 
country's specific generational characteristics are less prevalent in their case, as members of this generation are affected by the same events all over the world and behave according to the same trends (Pál 2013). This virtual world gives freedom to them that they may be those who want to. The situation is made easier that they can easily retire from this life at any time, they can turn it off. According to György Csepeli, this space is about to become a drug for them, where everything can be realized (Csepeli 2006).

The members of Generation $\mathrm{Z}$ can be described by the following characteristics (Tari 2011; Levickaite 2010; Ferincz and Szabó 2012; Csepeli 2006; Schlossberg 2016; Pierog, Erdei, and Gergely 2016; Cooman and Dries 2012; Hack-Handa and Pintér 2015; Hegedüs 2015; Zsarnoczky 2016):

- Because of globalization, this generation matures sooner and it grows up faster. Also for the sake of globalization, they can easily prosper in today's multicultural world.

- Both socially and technologically self-determined generation. Therefore, they do not like limiting them either online or offline, and they do not like rules, but they are much less likely to comply with them than previous generations.

- Social media is an important part of their lives, typical in sharing of different contents. They are characterized by narcissistic behaviour on social networks. They are constantly uploading images about themselves and their life events, which are presented as more beautiful as they really are. They handle technology in a professional way, and they use it most to express their personality. Members of this generation hide behind avatars as their virtual identities. Virtual existence seems to be much safer for them, so they are locked in, and they break down their circle of friends in their real lives.

- They belong to clit, which unites them in appearance and thinking, though they want to show their uniqueness.

- They find it difficult to express their emotions, but are very sensitive.

- They are not afraid of change because they live in an age of constant development and innovation. Because of this, they are brave, initiators, since there is no fear of change.

- They are characterized by a practical approach; they are creative, innovative, smart and have a good problem-solving ability.

- They are inexhaustible for knowledge, but they lack critical thinking. 
- They adopt very few adult role models, and the most authentic faces are people from their age group who have a high level of achievement in some field, or at least a reputation. People who are present today do not want to look up, but face them.

- They can do more than one thing at a time (multitasking), though only for a short time, so speed becomes more important than precision. They'd rather trust only in themselves, nothing else really.

- As consumers, they have high expectations for the products they buy, but they are not brand-conscious, less loyal. The experiences gained during the purchase are of special importance to them.

- Compared to previous generations, they live in a much fasterpaced life. In the world of work, they are self-confident, flexible and strive to secure their future. They have no doubts about their own abilities, their limitations, they also can be even unscrupulous, if needed.

- They respect the older generation, especially those who are their elderly family members. For example, members of the $\mathrm{Z}$ generation more willing to go on a holiday with their grandparents instead of closer family members.

Although the members of the $\mathrm{Z}$ generation are still young, some of their preferred values and patterns of thinking seem to outline what they consider important: personal freedom, sharing goods, free access to cultural goods, environment protection, digital information, blindly believe in everything that is conveyed by the celebrities, the role of externalities (mobile phones, clothing, etc.), the views of peer groups, cheerfulness, integration, speed, customizability, worklife balance, career, team spirit, cooperation, happiness - if that is not it, they go away (Ferincz and Szabó 2012; Tari 2011; Tari 2011; Pierog, Erdei, and Gergely 2016; Cooman and Dries 2012; Hegedűs 2015).

The beliefs that endorsed by the $\mathrm{X}$ and the $\mathrm{Y}$ generations of privacy, love, and family values have become obsolete for the $Z$ generation. From the characteristics and values of the $\mathrm{Z}$ generation, young people are very mobile and success-oriented. The consequence is the easy abandonment of hometowns, the search for better and better opportunities, and the continuous intention for the improvement of living and recreational conditions. For this reason, keeping young people in town is a particularly difficult task (Berkesné, Birkner, and Ernszt 2017). 


\section{Keeping Z Generations in Place}

My research focuses on the problem with which many domestic and rural settlements are struggling: the migration of young people. This long-lasting problem in the rural environment has continued to ring in the 2010 s and now affects not only villages, small towns, but also rural towns. The results of a research conducted in the Transdanubian region by executives of middle-size cities show that young people can be kept in the city by providing quality jobs, appropriate events, a good higher education system and further education opportunities, entertainment, cultural events, youth clubs, community spaces, business start-up support, identity enhancement within the school system, sport facilities, and safety (Berkesné, Birkner, and Ernszt 2017). The above-mentioned research emphasized that 'an opened management approach is also needed, that is able to set old patterns aside' and fits to the needs of future generations (Berkesné, Birkner, and Ernszt 2017).

In my empirical research, I take into account those actors that act in a non-profit-making way but in the direction of social interests; that is to say, what can the non-business sector (local government, municipal government, public utilities, civil spheres, educational units) make in terms of marketing in order to accommodate talented young people. I set up an interview questionnaire to help me assess the views of the representatives of the above actors. The territorial aspect of my research focuses on a Hungarian middletown, where I had 21 interviews with the leader of non-business organisations between 6th and 28th of February 2018. I made personal interviews based on a structured questionnaire. The sample was given by the leaders of non-profit institutions, public utilities and public services. The interviews partly focused on the identity of the leaders, their impressions about the town, on the characteristics of Generation Z, and on what such a non-business institution can do in order to keep them in the town.

\section{Results of the Empirical Research}

All the interviewed leaders can be called local patriots, since measured on a four-grade scale, their ties to the town average to 3.48 . Only 1 person indicated his/her attachment 1 or 2 , and 13 out of 21 mentioned that they are fully committed to the town. Since the analysed institutions belong to the non-business sector, it is not surprising: all the organisation is working in order to serve the public, the local people. Only a person that has the necessary knowledge and 
TABLe 2 Town Evaluation on a Four-Grade Scale, Total Number of Evaluators

\begin{tabular}{|c|c|c|c|c|c|c|}
\hline \multirow[t]{2}{*}{ Statements about the town } & \multicolumn{4}{|c|}{ Scale } & \multirow[t]{2}{*}{$(1)$} & \multirow[t]{2}{*}{$(2)$} \\
\hline & 1 & 2 & 3 & 4 & & \\
\hline $\begin{array}{l}\text { The town offers sufficient quality and range } \\
\text { of employment opportunities. }\end{array}$ & o & 8 & 11 & 2 & 21 & 2.71 \\
\hline Housing conditions are adequate in the town. & o & o & 7 & 14 & 21 & 3.67 \\
\hline The quality of educ. in high school is high in the town. & 1 & 4 & 8 & 6 & 19 & 3.00 \\
\hline There are many leisure events in the town for young. & 2 & 10 & 7 & o & 19 & 2.26 \\
\hline $\begin{array}{l}\text { There are plenty of community spaces in the town } \\
\text { where young people can spend their free time. }\end{array}$ & 4 & 9 & 4 & o & 17 & 2.00 \\
\hline The town has a vibrant community life. & 7 & 9 & 4 & 1 & 21 & 1.95 \\
\hline There are plenty of sports facilities in the town. & o & 6 & 11 & 4 & 21 & 2.90 \\
\hline City traffic is good enough. & 2 & 1 & 16 & 2 & 21 & 2.86 \\
\hline Local public services are accessible on a high standard. & o & o & 10 & 10 & 20 & 3.50 \\
\hline The town is the ideal place to start a business. & o & 5 & 6 & 9 & 20 & 3.20 \\
\hline The town's future is predictable, safe. & 2 & 9 & 8 & 2 & 21 & 2.48 \\
\hline
\end{tabular}

Notes (1) total, (2) mean.

tie to the town, and a kind of responsibility for the local people, can lead such an institution.

Based on the list by Berkesné, Birkner, and Ernszt (2017), I asked the interviewees to evaluate their home city. Not all the interviewed people could answer ro all the queations on the evaluation sheet; however, we could calculate an average. In table 2 we can see how many interviewee mentioned a different value on the four-grade scale. We can see also the total number of evaluators and the mean of given answers. Regarding the work opportunities, the interviewees are moderately satisfied, the average is 2.71; however, two persons mentioned that the opportunities are absolutely given. The housing conditions got the highest mean (3.67), all the interviewee gave 3 or 4 point to this aspect. They also think that the education in the high schools is good, but the mean of the leisure events are modest (2.26). Nobody gave four for this aspect, just as in the case of community spaces. The lowest mean belongs to the vibrant community life (1.95), and here is the highest ratio of point 1 (seven interviewees indicated this scale value and further nine the 2). The sport facilities in the town could be better (2.90), as the traffic (2.86). On the other hand, the local public services got good evaluation (3.50). One of the most critical questions on this list was about the town's future. Two interviewees were pessimistic and said that not just the town, but also even the whole rural area does not have the future.

In order to get a deeper insight into their opinion on the town- 


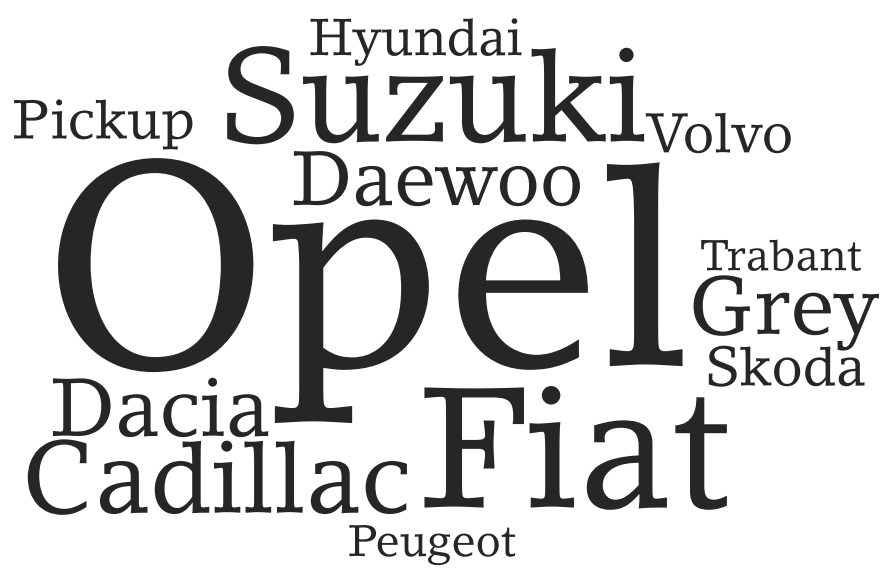

FIgURE 1 The Town As a Car Brand

scape, associative tasks were given to the interviewees: Imagine the city as a car brand! Which car brand and what features do you think are similar to the town's properties? In figure 1, I summarized all the car brands that were mentioned. Beside this perhaps even more important are the features on which the car brand/animals were identified by the respondents.

Six interviews mentioned that the town is an Opel, three of them said Suzuki and two said the Fiat. The other car brands were mentioned individually. In the table 3, I collected the features that the respondents mentioned regarding the car brands. Opel, as a brand, is considered as a solid, safe car, which is not the best category, but it could be enough. Overall, according to the respondents, the dynamism is lacking in the town, which is somehow oriental in style, less creative or innovative. Although it is functional and there are no problems, its capabilities are not exploited.

In the second part of my research, I focused on the generation $\mathrm{Z}$ and its characteristics. During the literature overview, I found lot of attributes identified by different researches. My initial thought was that these characteristics are not necessarily true of the members of the generation $\mathrm{Z}$ in Hungary; furthermore, some characteristics can be considered more age-edge peculiarity, and could be traced in all generations in their ten-twenties. To justify or reject this assumption I listed 23 attributes in my interview question list and asked the interviewees to decide: are they not characteristics of generation $\mathrm{Z}$, are they characterizing some of young people but not in general, or are typical for almost everybody in the generation $Z$. The results can be seen in table 4 . 
TABLE 3 The Town's Characteristics If It Would Be a Car

\begin{tabular}{ll}
\hline Car brand & Feature \\
\hline Opel & $\begin{array}{l}\text { Groovy, mass car; reassuringly safe, non-aggressive, non-galloping } \\
\text { car; not fast, but not slow, suitable for the purpose; never knock out; } \\
\text { lower middle class; survivor }\end{array}$ \\
\hline Suzuki & $\begin{array}{l}\text { Not very dynamic, it's not modern but it works safely and works reli- } \\
\text { ably; relatively reliable, accessible to many; but not a fast, non-luxury } \\
\text { category. }\end{array}$ \\
\hline Fiat & $\begin{array}{l}\text { Not too big, relatively reliable, interesting car. Italian; ot on the stage, } \\
\text { it is on a periphery, gotten-worn. }\end{array}$ \\
\hline Cadillac & $\begin{array}{l}\text { Large, slightly slow but powerful engine, it only needs to press the ac- } \\
\text { celerator; it needs technological development. }\end{array}$ \\
\hline Dacia & Eastern type, but there are Western features in it. \\
\hline Daewoo & It looks more from the outside than from inside. \\
\hline A grey auto & It may be nice, but mediocre; it could be better. \\
\hline Hyundai & $\begin{array}{l}\text { Eastern, capable of development, with leading indicators brand, open } \\
\text { thinking. }\end{array}$ \\
\hline Peugeot & $\begin{array}{l}\text { It may also be good because the features are there, but there are some } \\
\text { assembly problems that later expel. }\end{array}$ \\
\hline Pickup & $\begin{array}{l}\text { There is no full comfort feature; the conditions are good but there } \\
\text { are missing elements. it is well loaded, it has many sticks, but it is not } \\
\text { self-sufficient, it needs help. }\end{array}$ \\
\hline Skoda & $\begin{array}{l}\text { There are some features that are not necessarily the best, but it is do- } \\
\text { ing its best to reach the peak and the top quality within these limits. }\end{array}$ \\
\hline Trabant & $\begin{array}{l}\text { Old, obsolete as time; it is not worth developing further, the wrinkle } \\
\text { removal will not help. }\end{array}$ \\
\hline It's safe. \\
\hline
\end{tabular}

It is quite true for the generation living in the examined settlement that it is important for them to have fun and to be happy if that is not the case, they leave. The members of the generation have a hedonistic attitude and the 'live for today' thinking is typical, so the happiness is an ultimate question for them. Like just everybody in the 21th century they have a fast pace of life. It means that they require quick information gathering, administration, and instant solutions. They are in constant rush. It is also typical that they do not really accept the adult models. In communication with this generation, this must be taken into account and they can invite to a program by involving actors, opinion leaders from their age. The 'multitasking' (attention-sharing, duplicate actions) and the denial of rules are also typical for them, as they do not like any kind of limitations and want personal freedom. This generation lives according to their own rules, do not like to depend on anyone. They want to do 
TABLE 4 Characteristics of Generation Z According to the Respondents

\begin{tabular}{lrrrr}
\hline Characteristics & $(1)$ & $(2)$ & $(3)$ & $(4)$ \\
\hline Use a technology to express their personality & 0 & 2 & 16 & 2.89 \\
They have a fast pace of life & 0 & 4 & 17 & 2.81 \\
Do not like limiting them & 1 & 2 & 18 & 2.81 \\
Personal freedom is important to them & 1 & 1 & 18 & 2.85 \\
'Multitasking' (attention-sharing, duplicate actions) & 2 & 1 & 18 & 2.76 \\
It is important to have fun and happiness - if that is not the & 1 & 3 & 16 & 2.75 \\
case, they leave & & & \\
A provocative, extreme, spectacular, show-like serving is & 1 & 4 & 16 & 2.71 \\
important to them & & & \\
Accepting few adult models, the most authentic faces are people & 4 & 3 & 14 & 2.48 \\
who are fame from their age & & & & \\
Does not like the rules & 5 & 3 & 13 & 2.38 \\
Clutches that unify them with appearance and thinking, even if & 2 & 5 & 14 & 2.57 \\
they want to see their unique character & & & \\
The information can only be received in digital form & 2 & 6 & 13 & 2.52 \\
Less loyal & 3 & 7 & 11 & 2.38 \\
They can hardly express their emotions & 3 & 7 & 10 & 2.35 \\
They are not afraid of the changes & 4 & 6 & 11 & 2.33 \\
Confident, do not doubt their own abilities & 4 & 7 & 10 & 2.29 \\
Narcissist & 2 & 10 & 7 & 2.26 \\
The uniqueness and customizability are important to them & 6 & 5 & 10 & 2.19 \\
Creative & 5 & 7 & 9 & 2.19 \\
To people who are sample today, do not want to look up, but face & 5 & 7 & 7 & 2.11 \\
them & & & \\
Brave, initiating & 5 & 10 & 6 & 2.05 \\
Good problem-solving ability & 6 & 9 & 6 & 2.00 \\
Intended to make sure their future & 9 & 5 & 7 & 1.90 \\
Practical features & 7 & 13 & 1 & 1.71 \\
\hline
\end{tabular}

Notes (1) it is not characteristic of them, (2) characteristic of some young people but not in general, (3) almost everybody in the Z generation, (4) mean.

what they want, what is good for them, which is just the mood. Using technology to express their personality also belongs to the behaviour that they consider self-regained. The members of the Generation $\mathrm{Z}$ can be catched only by provocative, extreme, spectacular, show-like serving.

The interviewees declined that the young people in the examined town would belong be a pragmatic-minded generation; in fact, they reported that generation $\mathrm{Z}$ has very little practical knowledge or thinking. They also think that this generation live only for today and do not plan their future. 
Regarding the other characteristics mentioned in the literature overview, I can say that it cannot be clearly stated that they are true for the $\mathrm{Z}$ generation in the examined settlement. Many respondents thought that although for some young people they are true, they certainly cannot be generalized for the whole Hungary. Many interviewees reported also that some properties, like being narcissist and self-confident, having no doubt about the own abilities or not being afraid of the changes were true also for them in their young age, or maybe even today.

I have started this chapter with a list of elements about what is important to the young people at a mid-size town. The aim of this research was to identify those elements which can help keep the young people in the (home)town. Based on this list, I have tried to reuse this research and asked my respondents about the importance of this factor in the Hungarian middle towns. I asked the respondents to name and rank three factors, which they consider as the most important for a young person at his place of residence. In table 5 is visible that the public services, the business start-up support and the urban transport has never been mentioned among the three most important factors. 20 person out of 21 mentioned the appropriate job opportunities among first three factors, so it seems that this is the most important factor. 11 interviewees out of 20 mentioned it at the 1st place, seven further at the 2nd place and two at the 3 rd place. Nine respondents said that the most important factor is having a personal vision in the town (meaning carrier, family, safety, good prospects in all area of life). Two further mentioned it at the 2nd and four at the 3 rd place. Total of 15 respondents put the vision to the podium. 14 interviewees think that the recreation options, like community places, events, and a vibrant social life are also crucial to the young people. Only one person put this factor in the 1st place, but eight mentioned it as a 2nd most important element and further five as a 3 rd factor. The other items (education, housing, sport opportunities) are far behind, so the respondents' opinion on the key issues of keeping young people is clearly drawn. The appropriate job, the personal vision and the recreation options are the most important to the generation $\mathrm{Z}$.

Finally, I would like to mention some suggestions based on the interviews that may help to keep the young people in a middle-size town. I present the ideas of respondents without name and organizational form.

Most of the suggestions (5) were related to the community building, especially developing different spaces to the citizens. Among the 
table 5 Rank of Factors That Can Help to Held the Young in the Hometown (Number of Mentions)

\begin{tabular}{lrrrr}
\hline Factors & $(1)$ & $(2)$ & $(3)$ & $(4)$ \\
\hline Appropriate job opportunities (quality, choice, income) & 20 & 11 & 7 & 2 \\
Vision (predictability, value systems, security) & 15 & 9 & 2 & 4 \\
Recreation (community life, youth squares, champagne, choice) & 14 & 1 & 8 & 5 \\
Education (adequate education system, standard, choice) & 7 & 1 & 3 & 3 \\
Housing (affordable, high quality, diverse) & 5 & 0 & 1 & 4 \\
Sport facilities & 2 & 0 & 0 & 2 \\
Public services (availability, level) & 0 & 0 & 0 & 0 \\
Business start-up support & 0 & 0 & 0 & 0 \\
Urban transport, accessibility (pedestrian, community, fast) & 0 & 0 & 0 & 0 \\
\hline
\end{tabular}

Notes (1) all mentions among the top three, (2) mentioned at place 1, (3) mentioned at place 2, (4) mentioned at place 3.

ideas, the youth centre development, the youth community space establishment, and new entertainment facilities were mentioned, for both outdoor and indoor activities. A special idea also came up; it was the development of a lake next to the city with a range of recreational facilities. Three of the respondents said that before thinking about how we can keep the young in the town, the town has to define itself. Finding the unique characteristic, the identity, is crucial. However, the interviewees have not mentioned what could be this uniqueness. Interestingly, three ideas were related to different sport topics. An interviewee mentioned that by buying a professional sport team the local identity could raise and help to create a real community in the town, which is good to belong to. Three respondents think that by developing the education the young people would stay in the town. They are thinking about some specializations or those kinds of trainings for adults, which also can help to develop the local patriotism. The different scholarship programs also were mentioned three times at three different areas: scholarships to solve the skilled workforce shortage, scholarship in the form of training grants for students, and scholarship for the trainees to keep them after school. Two people mentioned that creating a knowledge centre would be a solution, because here the research and innovation would be supported, thereby creating value-added jobs. These incubators should be specialized on Iт or geothermal resources. In addition, two ideas were about different concept-developments. It was said that creating a concept is needed before any action plan. The interviewees mentioned that professional companies should create the urban development policy, or to help with attraction of foreign investors. 
TABle 6 Proposed Actions to Keep Young People

\begin{tabular}{|c|c|}
\hline $\begin{array}{l}\text { Development of a } \\
\text { community space (5) }\end{array}$ & $\begin{array}{l}\text { - youth center, youth community space } \\
\text { - development of entertainment facilities } \\
\text { - development of a lake next to the city with a range of } \\
\text { recreational facilities } \\
\text { - both outdoor and indoor }\end{array}$ \\
\hline $\begin{array}{l}\text { Development of a } \\
\text { unique attraction, } \\
\text { image (3) }\end{array}$ & $\begin{array}{l}\text { - unique image, everything can be grounded on it, eg. stilts } \\
\text { - tourist-attractant and economy developer attraction } \\
\text { - initially, demand must be maintained artificially }\end{array}$ \\
\hline Sport (3) & $\begin{array}{l}\text { - buying a professional sport team (basketball, handball, } \\
\text { futsal) } \\
\text { - professional sport development (cycling) } \\
\text { - sport infrastructure development }\end{array}$ \\
\hline Education (3) & $\begin{array}{l}\text { - specialized music school } \\
\text { - community building camps, trainings }\end{array}$ \\
\hline $\begin{array}{l}\text { Scholarship program } \\
\text { (3) }\end{array}$ & $\begin{array}{l}\text { - solve the skilled workforce shortage in the form of } \\
\text { training grants to the trainees to keep them after school }\end{array}$ \\
\hline Incubator and $\mathrm{R}+\mathrm{D}(2)$ & $\begin{array}{l}\text { - specialized on the topic of Iт or geothermic resource } \\
\text { - where research and innovation be supported, thereby } \\
\text { creating value-added jobs }\end{array}$ \\
\hline $\begin{array}{l}\text { Development of a } \\
\text { vision, concept (2) }\end{array}$ & $\begin{array}{l}\text { - international tender for the development of urban } \\
\text { development policy } \\
\text { - investment offeror }\end{array}$ \\
\hline $\begin{array}{l}\text { Others mentioned by } \\
\text { one-to-one } \\
\text { respondents }\end{array}$ & $\begin{array}{l}\text { - supporting young people becoming entrepreneurs (1) } \\
\text { - settlement pays (1) } \\
\text { - a complete transition to renewable resources (1) } \\
\text { - job creation (1) } \\
\text { - improving working conditions at the institution (1) } \\
\text { - institutional profile extension (1) }\end{array}$ \\
\hline
\end{tabular}

Further thoughts were about supporting young people to become entrepreneurs, about a complete transition to renewable resources, and any kind of job creation actions. Two respondents highlighted their own institutions problem; in order to keep the young people in the town they would like to retain their own workforce. From this reason, they suggested to improve working conditions at the institution.

\section{Conclusion}

The purpose of my research was explore characteristics and values of the Generation $\mathrm{Z}$, and to reveal which characteristics of these are true to young Hungarians. As the emigration of talented youngsters touches not only villages, but also small and medium-sized cities, I wanted to highlight whether members of the Generation $\mathrm{Z}$ feel attached to their hometown and if such a city can offer them a good 
vision. Based on the generation characteristics, which areas should be developed and what are the demands of today's 13-23 year olds.

By interviewing the local non-business sphere, I presented the judgment of the various settlement features through an example of a middle-town in Hungary. We could see that it more or less has the most important ingredients, except the issues related to the recreation. Local patriots think that the town do not have a vibrant community life, and that there are not many leisure events or community space for young people. Even these committed institution leaders are sceptic about the town's future and success of the developments. According to the respondents, the dynamism is lacking in the town, which is somehow oriental in style, less creative or innovative. 21 interviewees think that the town has no personality, no uniqueness. This is also confirmed by the fact that the respondents named 13 different car brands. The town is not courageous, non-initiator, rather shy, retractable. They see the town as a safe place, which is able to stick anything, but it should be dynamic, because it is very slow at present, the progress takes too much time.

Local actors believe that the members of the Generation $\mathrm{Z}$ use technology to express their personality; they have a fast-paced life; personal freedom is important to them; 'multitasking' (attentionsharing, duplicate actions) is typical; it is important to them to have fun and happiness - if that is not the case, they leave; the provocative, extreme, spectacular, show-like serving is important to them; accepting few adult models, the most authentic faces are people who are fame from their age. The improvements proposed by non-business institutions show almost complete consistency with these generation features. Most people have suggested the development of community spaces that create autonomy and happiness. A legitimate expectation of the generation $\mathrm{Z}$ that adults or older people do not appear in this space, they would only meet their own age group. For this reason, it is important to know what they want to do there - that is to say, the youngsters must be involved in the creation of spaces. The second most important suggestion was the finding of uniqueness and its provocative, astonishing interpretation. This is partly related to the previous ones with so many additions that young people expect a 'cool' thing that is extreme and what they themselves can be proud of. For this, the pool table and bowling are not enough. Experience is what we need to work for, and in what we can be a part, we are developing by it. You can imagine a climbing wall track, a laser battle track or simulation games in this area.

Overall, the directions in which the time passed away by genera- 
tion $\mathrm{Z}$ in their hometowns can be considered as a real experience is very well outlined. The above activities and developments all provide for the possibility of enjoying personal freedom, extremity, multitasking and happiness; and finally yet importantly promote community raising. By the positive childhood and adolescent experiences, the bondage to the settlement and the identity will be strengthened.

\section{Acknowledgements}

This research was supported by the ÚNKP-17-4 New National Excellence Program of the Hungarian Ministry of Human Capacities.

\section{References}

Árvané Ványi, G., J. Katonáné Kovács, P. Popovics, and T. Gál. 2017. 'A Z generáció felsőoktatással kapcsolatos motivációinak és elvárásainak vizsgálata.' International Journal of Engineering and Management Sciences 2 (4): 1-13.

Bálint, B. 2016. 'A Z generáció karriertervezése а Рте ктк-n.' Taylor Gazdálkodás- és szervezéstudományi Folyóirat 8 (4): 65-76.

Berkesné, R. N., Z. Birkner, and I. Ernszt. 2017. Köldökzsinór: A Pannon Városok Szövetségéhez tartozó városok sikerének és megtartó erejének kulcstényezói. Kőszeg: Felsőbbfokú Tanulmányok Intézete.

Cooman, R., and N. Dries. 2012. 'Attracting Generation Y: How Work Values Predict Organizational Attraction in Graduating Students in Belgium.' In Managing the New Workforce, edited by E. S. Ng and L. T. Sean, 44-63. Cheltenham: Edward Elgar.

Csepeli, G. 2006. 'A jövőbe veszett generációk.' In Magára hagyott generációk, edited by G. Csepeli, É. Kígyós, and P. Popper, 1-12. Budapest: Saxum.

Eskilson, A., and M. G. Wiley. 1999. 'Solving for the X: Aspirations and Expectations of College Students.' Journal of Youth and Adolescence 28 (1): 51-70.

Ferincz, A., Z. R. Szabó. 2012. 'Z generáció hatása a munkáltató szervezetekre.' Munkaügyi Szemle 56 (2): 88-93.

Hegedûs, H. 2015. 'xxi. századi kihívások: HR-megoldások a köz- és a versenyszférában.' Hadtudomány 25:102-07.

Hack-Handa, J., and R. Pintér. 2015. 'Generációs különbségek a magyar médiafogyasztásban.' Információs társadalom 15 (2): 7-17.

Lancaster, L. C., and D. Stillman. 2002. When Generations Collide. New York: Harper Business.

Levickaitè, R. 2010. 'Generations X, Y, Z: How Social Networks Form the Concept of the World without Borders.' Limes 3 (2): 170-83.

Levy, L., B. Carroll, J. Francoeur, and M. Logue. 2005. The Generational Mirage? A Pilot Study into the Perceptions of Leadership of Generations $X$ and $Y$. Sydney: Hudson Global Resources. 
Malota, E. 2011. Kultúrák és kommunikáció: Esettanulmányok és gyakorlatok. Budapest: ВСЕ.

Malota, E., and A. Mitev. 2013. Kultúrák találkozása: Nemzetközi kommunikáció, kultúrsokk, sztereotípiák. Budapest: Alinea.

Mannheim, K. 2001. 'A nemzedékek problémája.' In Tudásszociológiai tanulmányok, edited by Z. Szántó and A. Wessely, 201-54. Budapest: Osiris.

McCrindle, M., and E. Wolfinger. 2009. The Авс of xyz: Understanding the Global Generations. Sydney: unsw Press.

McCrindle Research. 2012. Generations Defined. http://mccrindle.com .au/resources/Generations-Defined-Sociologically.pdf

Mutte, J-L. 2004. 'Managing workers of the next decade.' https://www .expatica.com/hr/hr-global-strategy/Managing-workers-of-the -next-decade_20382.html

Oblinger, D. G., and J. L. Oblinger. 2005. Educating the Net Generation. Washington, DC: Educause.

Pál, E. 2013. 'A “Z" generációról: Áttekintő tanulmány.' http://www .zgeneracio.hu/getDocument/4252

Parry, E., and P. Urwin. 2011. 'Generational Differences in Work Values: A Review of Theory and Evidence.' International Journal of Management Reviewes 13:79-96.

Pierog, A., P. Erdei, and É. Gergely. 2016. 'A Z generáció vezetőkkel szembeni elvárásai.' International Journal of Engineering and Management Sciences 1 (1). https://doi.org/10.21791/IJEMS.2016.1.39

Prensky, M. 2001. 'Digital Natives, Digital Immigrants I-II.' On the Horizon 9 (5): 1-6.

Tari, A. 2011. Z generáció. Budapest: Tercium.

2015. \#yz Generációk Online. Budapest: Tercium.

Törőcsik, M., K. Szűcs, and D. Kehl. 2014. 'Generációs gondolkodás: A Z és az Y generáció életstílus csoportjai.' Marketing \& Menedzsment 2 (special issue): 3-15.

Schlossberg, M. 2016. 'Teen Generation Z is Being Called "Millennials on Steroids," and That Could Be Terrifying for Retailers.' Business Insider, 11 February. http://uk.businessinsider.com/millennials-vsgen-z-2016-2.

Steigervald, K. 2014. Milyen a ma élő нат generáció? Üzlet és Pszichológia, no. 6: 6-9.

Strauss, W., and N. Howe. Generations: The History of America's Future, 1584 to 2069. Fort Mill, sc: Quill.

Zsarnoczky, M. 2016. 'The Impact of Silver Tourism on Rural Areas.' Stowarzyszenie Ekonomistóv Rolnictwa I Agrobiznesu 18 (3): 402-10.

This paper is published under the terms of the Attribution-

NonCommercial-NoDerivatives 4.o International (CC BY-NC-ND 4.0)

License (http://creativecommons.org/licenses/by-nc-nd/4.o/). 